مجلة أبحاث ميسان ، المجلد السادس عشر، العدد الثاني والثلاثون ، كانون الأول، السنة

\title{
Clinical Study of Herpes Zoster In children \\ CLINICAL STUDY OF HERPES ZOSTER IN CHILDREN
}

\author{
DR.REYSAN MEHDI DAGHER \\ M.Bch.B D.D.V \\ Mobile: 07803462550 \\ Email: raisan_dagher@yahoo.com \\ AL-ZEHRAWI HOSPITAL - AMARA
}

This disease is one of the acute viral diseases due to the reactivation of the virus that causes chicken pox (chickenpox). This study was done to determine the age and gender of the infected, as well as the location of the infection and the type of clinical signs of the infected. injury . (31) cases of infection were recorded during the one-year period of the study, the average age of the injured was 6.6 years, the number of males was $17(54.8 \%)$ and the number of females (14) (46.2\%). The injuries are as follows: the chest area (12) 38.7\%) the lumbar region and the sacrum (14) (45.2\%), the neck area (5) (16.1\%), and for clinical signs the numbers were as follows: acute vesicular rash (22) $(71 \%)$, covered or covered rash (8) (25.8\%), post-infection neuritis (1) (3.2\%)

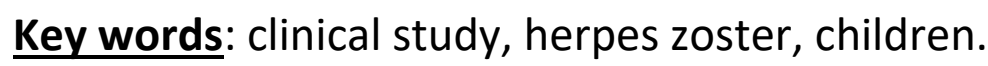


دراسة سريرية حول الحلأ النطاقي ( الهربس ) لدى الأطفال

\author{
د. بيسان مهدي داغر \\ 07803462550: الموبايل \\ raisan_dagher@yahoo.com: الايميل \\ اختصاصي جلدية وتناسلية \\ مستثفى الزهراوي / العمارة
}

: الملخص :

هذا المـرض مـن الأمـراض الفايروسية الحـادة بسبب إعـادة نشـاط الفايروس المسبب لجدري الدجاج ( الجدري المائي ) ، تم عمل هذه الدراسة لتحديد عمر وجنس المصابين وكذلك مكان الإصسابة ونوع العلامات السريرية لدى المصابين ، اعتمدت الدراسة على مسحة زانك لتأكيد التشخيص واعتمدت على مواقع الأعصساب الحسية الجلدية لتحديد مكان الإصابة .

تم تسجيل ( 31 ) حالـة إصـابة خـلال فترة عـام مـن الدراسـة ، كـان معدل عمـر المصـابين 6،6 سـنة ، عدد الذكور 17 ( 54,8 \% ) وعدد الإنـاث ( 14 ) ( 46,2 \% ) ) ، وفيمـا مـا يخص مكـان الإصـابة كان عدد هـ الإصـابات كما يأتي : منطقة الصدر ( 12 ) 38,7 \% ) المنطقة القطنيـة والعجز ( 14 ) ) ( 14 \% ) ) ؛ منطقة الرقبة ( 5 ) ( 16,1 \% ) ) ، وبالنسبة للعلامات السريرة كانت الأعداد كما يأتي : طفح حويصلي حاد ( ) 22 ) ( 71 \% ) ، طفـح مغطـى أو مكسـي ( 8 ) ( 25,8 \% ) ) التهـاب عصـبي بعـد الإصـابة ( 1 ) . $(\% 3,2)$

الكلمات المفتاحية : دراسة سريرية ، الحلأ النطاقي ( الهربس ) ، الأطفال .

Introduction:

Herpes Zoster or Shingles is an acute cutaneous viral infection caused by the 
مجلة أبحاث ميسان ، المجلد السادس عشر، العدد الثاني والثلاثون ، كانون الأول، السنة

2020

reactivation of varicella Zoster virus (VZV), aherpes virus that initially produces chickenpox and is characterized by unilateral pain and vesicular or bullous eruption limited to dermatome(s) innervated by a corresponding sensory ganglion. (1) Herpes Zoster is a primarily a disease of adults, more than $66 \%$ are over 50 years of age.

H.Z occur infrequently in healthy children and $5 \%$ of cases occur in children below 15 years. There is no sex difference in the incidence. The incidence of Herpes Zoster is 2-4 times higher in white patients than in blacks. (3)

Herpes Zoster has been noted as early as the first weak of life, this occurs in infants born to mother who have primary VZV infection during pregnancy. (4)

Risk

factors

Most common factor is diminished immunity to VZV with advancing age, Impaired function of CD4+ cytotoxic Tcells, such as found in patients with HIV infection, leukaemia, Hodgkins disease, or non-Hodgkin's lymphoma and those undergoing immune suppressive therapy or bone marrow transplantation.

\section{Transmission:}

Herpes Zoster is not a highly contagious condition, and the virus is not shed from the throat and therefore much harder for others to inhale. This means that the risk of contracting the VZV from someone with Shingles is low. The infection can theoretically be passed on during the time that the rash (blisters or sores) is visible. Healing scabs are not infectious. (5)

\section{Clinical feature:}

Herpes Zoster manifests in three distinct clinical phases. Prodromal, acute, and chronic stage.

Prodromal stage : neurotic pain or paraesthesia precedes cutaneous eruption by 3 to 5 days (range 1 to 14 days).

Acute stage :

Active vesiculation : from 3 to 5 days.

Crust formation : days to 2 or 3 weeks

chronic stage : post herpetic neuralgia (PHN)

\section{Skin symptoms:}

-prodromal stage : pain (stabbing prick, sharp, boring penetration, lancinating, 
مجلة أبحاث ميسان ، المجلد السادس عشر، العدد الثاني والثلاثون ، كانون الأول، السنة

shooting, tenderness, paraesthesia, itching, tingling, burning, freeze burning) in the involved dermatomes precedes the eruption.

Allodynia: heightened sensitivity to mild stimuli.

- active vesiculation : neurotic pain in the involved skin

- PHN : described as burning, ice-burning, shooting or lancinating can persist for weeks, months, and years after the cutaneous involvement has resolved.

constitutional symptoms:

.prodromal stage : headache, malaise, fever occur in about $5 \%$ of patients.

.active vesiculation : headache, malaise and fever

- chronic stage : depression is very common in patients with PHN. (1)

Dermatomes (site of predilections)

The cutaneous field of peripheral nerves

- Thoracic more than $53 \%$

- Trigeminal including ophthalmic 5\%

- Lumbosacral $11 \%$

- Cervical $20 \%$

These dermatomes at all ages but the relative frequency of ophthalmic Zoster increase in old age.

Mucous membrane: vesicles and erosions occur in mouth, vagina and bladder depending on dermatome involvement. (7)

Lymphadenophy: regional nodes draining the area are often enlarged and tender In ophthalmic Zoster, nasociliary involvement of ophthalmic branch of trigeminal nerve occurs. In about one third of cases and is heralded by vesicles on the side and tip of the nose (Hutchinson's sign) and its often leaves excruciating PHN. Although typically sensory nerves are affected, an occasional patient may experience motor nerve defects, facial palsy presents as the Ramsy Hunt syndrome, often accompanied by dizziness, vertigo, and taste abnormalities confined to the anterior tow third of the tongue, these features suggest facial or auditory nerve damage. (8)

\section{Diagnosis:}

Diagnosis usually involves obtaining a complete medical history of the child and 
مجلة أبحاث ميسان ، المجلد السادس عشر، العدد الثاني والثلاثون ، كانون الأول، السنة

performing a physical examination.

Diagnosis may also include:

- Skin scraping : Tzank smear used to examine cells from blistering conditions. (9) In Herpes Zoster smear of vesicle base or fluid show giant and / or multinucleated epidermal Cells.

- VZV antigen detection

Direct fluorescent antibody (DFA) detects VZV antigen in smear of vesicle base or fluid specific and very sensitive

- Polymerase chain reaction (PCR) from vesicular fluid can yield VZV antigen. (2)

- Viral culture : isolation of VZV

Dermatopathology: lesional skin biopsy shows acantholysis. Vesicle formation and giant and/or multinucleated keratinocytes (10)

Pathophysiology:

VZV during the course of varicella, pass from the skin lesions to the sensory nerves to travel to the sensory ganglia and establishes latent infection. Its postulated that humoral and cellular immunity to VZV established with primary infection persist at low levels and when this immunity ebbs, viral replication within the ganglion occurs. The virus then travels down the sensory nerves resulting in initial dermatomal pain followed by painful skin lesion.

Prodromal symptoms may appear initially in the trigeminal, cervical, thoracic, lumber or sacral dermatomes. PHN probably occurs as damaged nerves continue to misfire in the absence of active viral infection.

Approximately $20 \%$ of those people who have had varicella will get Zoster at some time during their lives. (11)

\section{Management:}

- Prevention

Varicella virus vaccine for use in children between age 1-12 years which is live attenuated vaccine provides long lasting resistance against varicella. (12)

Antiviral therapy : the efficacy of Acyclovir for treatment of primary and recurrent VZV infection in children has reduced the morbidity and mortality of these illness in immunocompromised children. (13)

Treatment of acute Herpes Zoster

The goals of management of Herpes Zoster include:

Minimize pain, reduced viral shedding, speed crusting of the lesions and healing, ease physical, psychological, emotional discomfort, prevent viral dissemination or other complications, prevent or minimize PHN.

Prodromal stage 
مجلة أبحاث ميسان ، المجلد السادس عشر، العدد الثاني والثلاثون ، كانون الأول، السنة

Begin antiviral agent if diagnosis is considered likely, analgesics.

-Active vesiculation: antiviral therapy begin before 72 hour accelerates healing of skin decreasing the lesion duration of acute pain and may decrease the frequency of PHN.

\section{Acyclovir (Zovirax):}

Nucleoside analogs are initially phosphorylated by viral thymidine kinase to eventually form nucleoside triphosphate which inhibit viral replication.

Paediatrics does as adult $250 \mathrm{mg} / \mathrm{m}$ per dose 4-5 times daily for 7-10 days. Famciclovir (famvir) and Valaciclovir hydrochloride (Valtrex) seem to be somewhat more efficacious than acyclovir $(14,15)$, but these medication are not approved by food and drug administration (FDA) for podiatric use. (2)

\section{Complication of Herpes Zoster}

.Secondary bacterial infection-

.Herpetic keratitis-

.PHN-

.Meningoencephalitis

Prognosis

.Rash and symptoms generally resolve within 14-21 days-

.PHN is rare in children- (18)

\section{Aim of the study:}

The study was conducted to characterize the occurrence, site of predilection, age and sex incidence of Herpes Zoster in children below 15 years old.

Patients and the methods

- 31 children affected by Herpes Zoster included in this study, their ages range from

2-15 years old with an average age of 7.4 years old

- Tzank smear (cytodiagnostic) is used to confirm the clinical finding in the Diagnosis.

- Coetaneous fields of peripheral nerves was used to determine the predilection sites.

\section{Results:}

A clinical study of 31 child suffered from Herpes Zoster infection visiting the outpatient clinic of Al-Zehrawi hospital in Amara department of dermatology from the period of January 2006 to December 2006

The children age group range from 2-15 years with an average of 6.6 years old. The number of male patients was $17(54.8 \%)$ and the number of females was $14(46.2 \%)$ The predilection site of the lesion (dermatomal segment affected) was as the 
مجلة أبحاث ميسان ، المجلد السادس عشر، العدد الثاني والثلاثون ، كانون الأول، السنة

following :

- Thoracic 12 (38.7\%)

- Lumbosacral 14 (45.2\%)

- Cervical 5 (16.1\%)

Clinical presentation of the patients was as the following:

- Active vesiculation 22 (71\%)

- Crusted lesions 8 (25.8\%)

- Post herpetic neuralgia 1(3.2\%)

SEX:

\section{NO. Of patients NO. Of male NO. Of female}

\section{1}

17

14

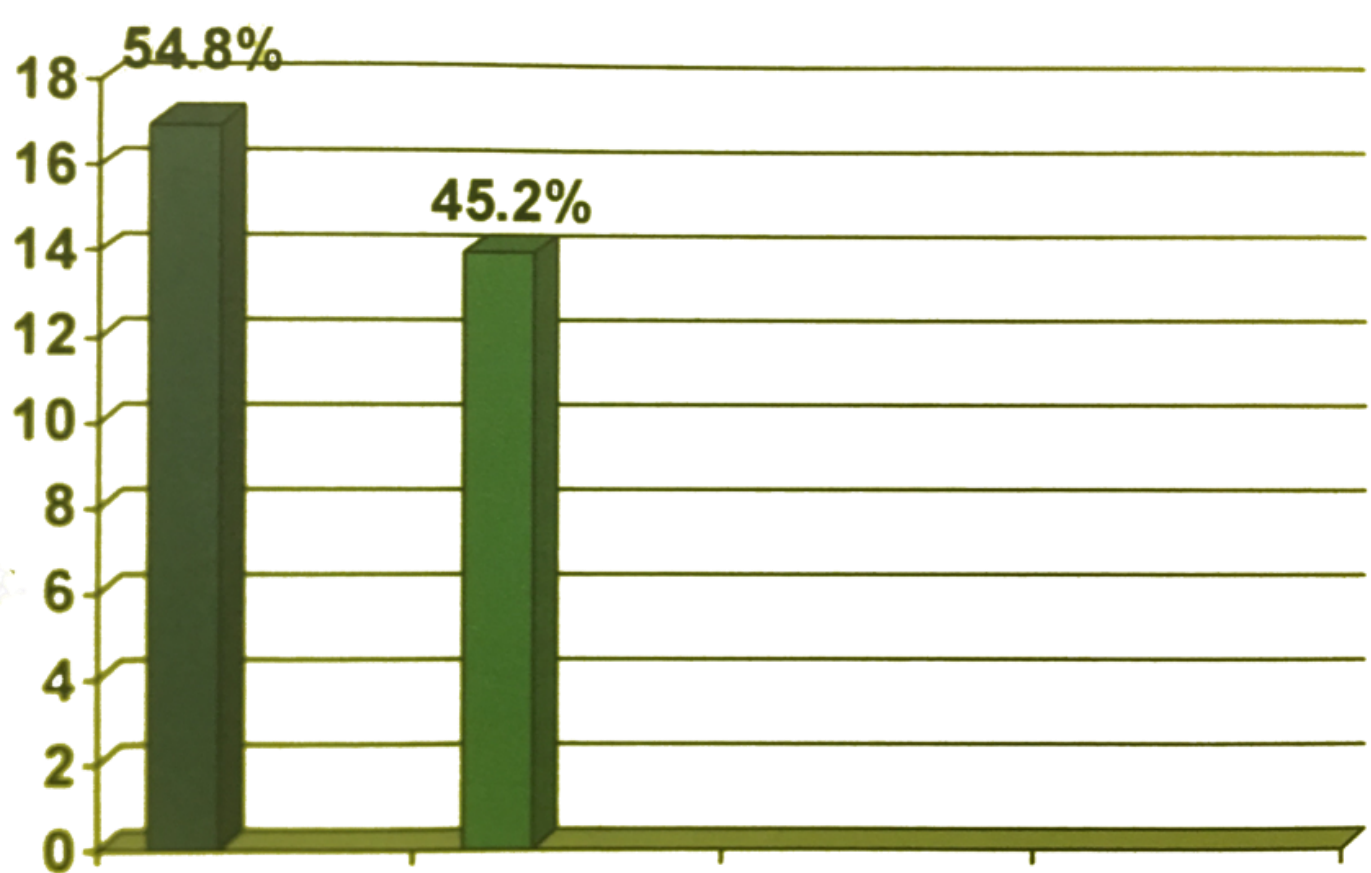

male female 
مجلة أبحاث ميسان ، المجلد السادس عشر، العدد الثاني والثلاثون ، كانون الأول، السنة

AGE:

\section{Age NO. Of patients Percentage \%}

$\begin{array}{ccc}2-5 \text { year } & 5 & 16.1 \% \\ 6-10 \text { year } & 20 & 64.5 \% \\ 11-15 \text { year } & 6 & 19.4 \%\end{array}$




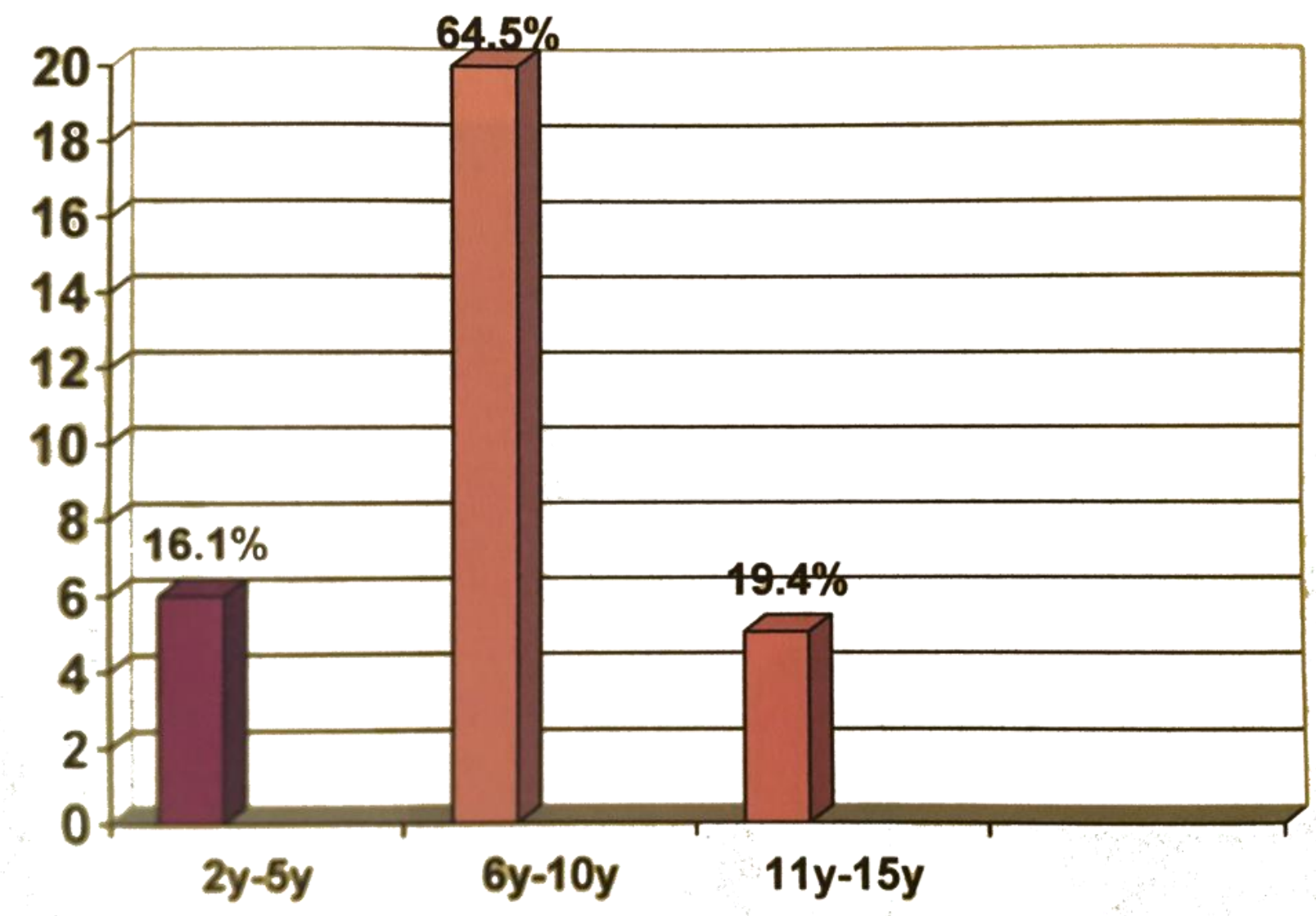

SITE:

\begin{tabular}{ccc}
\hline Site & NO. Of patients & Percentage \% \\
\hline Thoracic & 12 & $38.7 \%$ \\
Lumbosacral & 14 & $45.2 \%$ \\
Cervical & 5 & $16.1 \%$
\end{tabular}




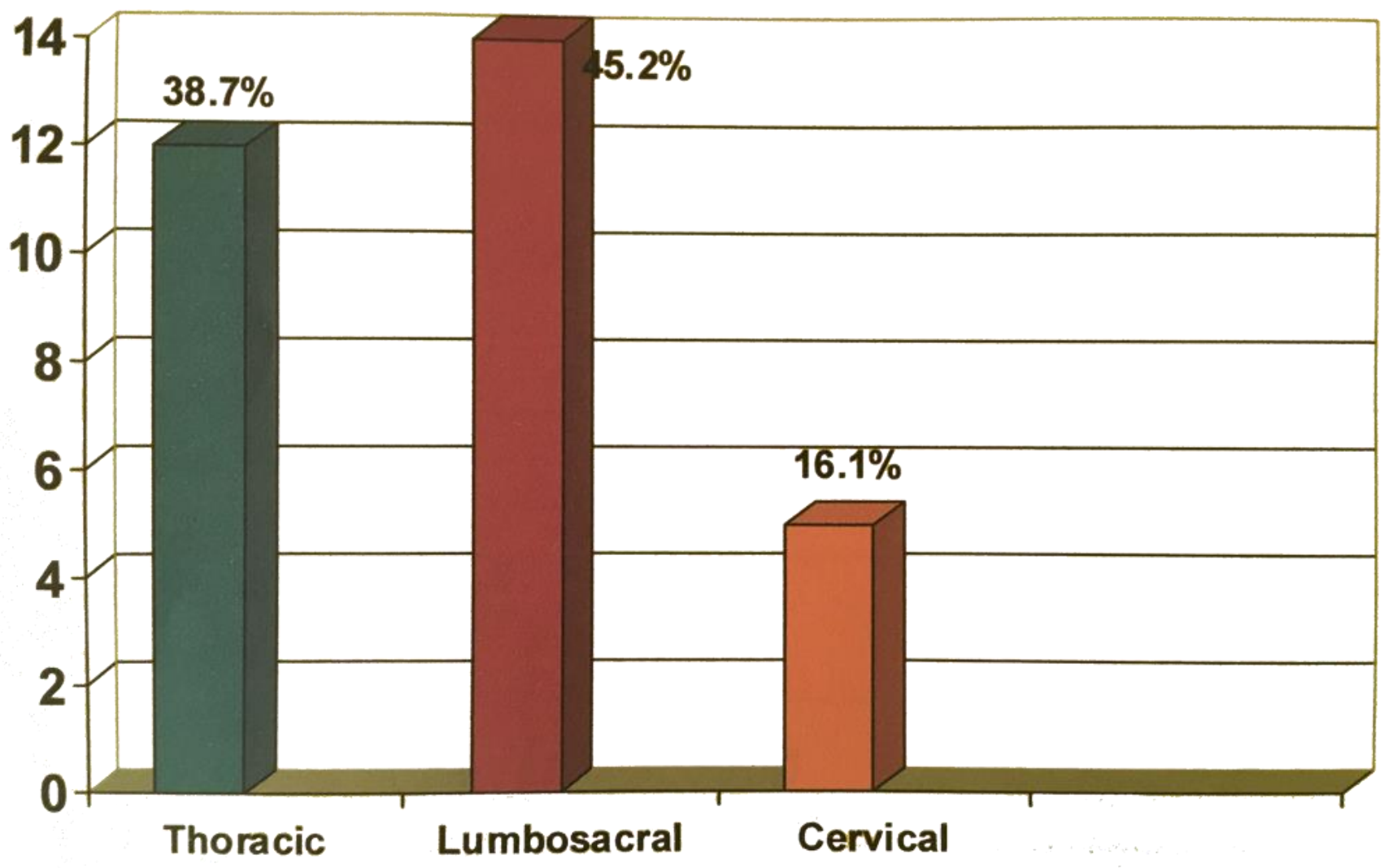

Clinical Presentation

\begin{tabular}{ccc} 
Clinical Presentation & $\begin{array}{c}\text { NO. Of } \\
\text { patients }\end{array}$ & $\begin{array}{c}\text { Percentage } \\
\%\end{array}$ \\
\hline Active Vesiculation & 22 & $71 \%$ \\
Crusted lesions & 8 & $22.8 \%$ \\
PHN & 1 & $3.2 \%$ \\
\hline \hline
\end{tabular}


مجلة أبحاث ميسان ، المجلد السادس عشر، العدد الثاني والثلاثون ، كانون الأول، السنة

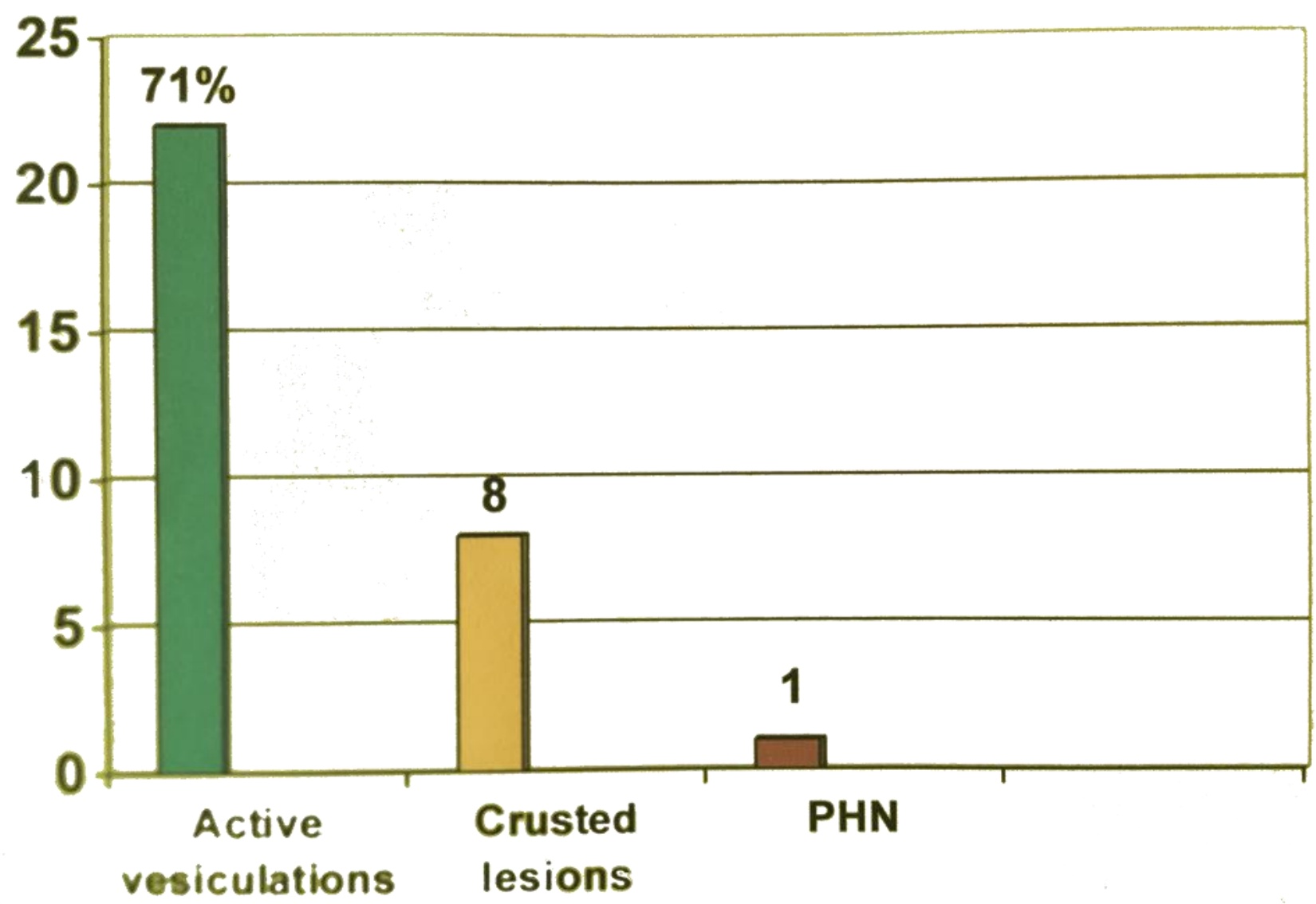

\section{Discussion:}

This clinical study involved 31 child affected by Herpes Zoster infection along period of one year I.e. from January 2006 to December 2006.

The children age group range from 2-15 years, although there are many cases of Herpes Zoster recorded below this age ( 2 years old), e.g. mothers of four children had varicella when in the third, sixth, eighth and fifth months of pregnancy respectively and the children were 3,24,14 and 8 months old when they had Herpes Zoster, and all of those children were healthy at birth, but there's risk. For the children to have congenital malformations when the mother developed varicella in the first months of pregnancy. (16) Also a case of Herpes Zoster in healthy 7 months old girl who had chicken pox at age of 4 Months. (17) 
مجلة أبحاث ميسان ، المجلد السادس عشر، العدد الثاني والثلاثون ، كانون الأول، السنة

Most of children affected by Herpes Zoster in this study were above 6 years old (school age) and this may explain why most of the children had varicella below or at school age and so the Herpes Zoster infection (reactivation of VZV) if happened will be after that age.

Although there is no sex differences in the incidence we noted in this study slight increase in the male children affected by Herpes Zoster and this may explained by the higher physical activity of the male children and this makes them more exposed to the infection by VZV.

About the predilection site (dermatomes) affected by Herpes Zoster, it is recorded that the thoracic segments are most commonly affected but in this study we found that the area mostly affected in the lumbosacral especially the area of the thighs and the buttocks in children (L1,L2 S2 and S3)

About clinical presentation, active vesiculation was the most clinical presentation in children and this may be because it's the first visible sign which attract attention of the parents to the disease but some cases will appear at the stage of crustation because of the short period of vesiculation and the absence of any symptoms or the neglection of the parents and so delated in doctor counselling. One case of PHN recorded in this study which is very rare in children and this case was with mild symptoms (burning and itching) and lasted only afew weeks.

\section{Conclusions:}

Herpes Zoster is rare in children, but may occur in infants even at the first few months, and this may be due to mothers affected by VZV infection at pregnancy and intra uterine exposure of the fetus to VZV, also it may be due to the early life infection by chicken pox of the infants.

Herpes Zoster infection is mild and self limited disease and it has occurred quite commonly in healthy children and not necessarily in immunosuppressed children. The frequency of occurrence of Herpes Zoster in children is relatively high and the number of children included in this study (31) in one hospital during aperid of a year supports that finding. 
مجلة أبحاث ميسان ، المجلد السادس عشر، العدد الثاني والثلاثون ، كانون الأول، السنة

\section{References:}

1-Australian Herpes Management Forum, Dr. Chris Miller -Shringles and post herpetic neuralgia 1999

2-eMedicine-zoster : Article by Andrea N Driano. MD 2002

3-Postgraduate Medicine - Acute and chronic herpes zoster by Ken Landow, MD 2000

4-Schmader K, George LK. Racial and psuchosocial factors for herpes zoster. K infect. Dis 1998.

5-liesegang TJ, Varicella zoster viral disease, Mayo Clin proc 1999.

6-Balfour HH Jr, Antiviral drugs. N Eng J Med 1999.

7-White CJ.Varicella zoster virus vaccine.clin infec dis 1997.

8-Rivas-da-la-Lastra. Rev-Med-Panama. Herpes Zoster in infants, 1995.

9-Elmer-KB, George-RM. Cutis. Herpes zoster in a 7-months infant 1999.

10-Takayama M,Takita-J, pediatric-infect, Dis. J 2000.

11-Leung-TF, Chick-KW. Incidence, risk factors and outcome of varicella zoster virus infection in children. 2000.

12-Avrahami-Heller-Y, Br. Med. J, immunity to varicella zoster virus. 2000.

13-Terada-K, Tanaka-H, Acla pediatr. Specific cellular immunity in immunocompetent Children with herpes zoster. 1998.

14-Kakourour-T. J-Am-Acad-Dermatol. Herpes Zoster In Children. 1998.

15-Kawano-S, Kataoka-N. Kansenshogako-Zasshi. Incidence of herpes zoster 16-Courter BJ, Pediatric herpes zoster. Pediatric Emerg Care 1993.

17-Piette ML, herpes zoster at school age. Hawaii Med J 1996.

18-Wurzel CL, Kahan J. Prognosis of herpes Zoster in healthy children, Am J Dis Children 1998.

19-Rona M. Machie, Clinical Dermatology. An illustrated textbook, Oxford Medical Publication, Herpes zoster, 1983.

20-Lionel Fry. Illustarted encyclopedia of dermatology, 2nd edition, herpes zoster 1985.

21-Arthur Rook, Textbook of dermatology. Herpes Zoster. 1992.

22-Fitz Patrick. Dermatology in general medicine, Varicella zoster infections. 1999. 